\title{
Seed inflow to a forest patch promoted by understory frugivorous birds
}

\author{
Verônica Souza da Mota Gomes ${ }^{1,2,4}$, Jorge Yoshio Tamashiro ${ }^{3}$ \& Wesley Rodrigues Silva ${ }^{1,2}$ \\ ${ }^{1}$ Laboratório de Interações Vertebrados-Plantas, Departamento de Biologia Animal, Instituto de Biologia - IB, \\ Universidade Estadual de Campinas - UNICAMP, CP 6109, CEP 13083-970, Campinas, SP, Brasil \\ ${ }^{2}$ Programa de Pós-graduação em Ecologia, Instituto de Biologia - IB, \\ Universidade Estadual de Campinas - UNICAMP, CP 6109, CEP 13083-970,Campinas, SP, Brasil \\ ${ }^{3}$ Departamento de Biologia Vegetal, Instituto de Biologia - IB, \\ Universidade Estadual de Campinas - UNICAMP, CP 6109, CEP 13083-970, Campinas, SP, Brasil \\ ${ }^{4}$ Corresponding author: Verônica Souza da Mota Gomes, e-mail: vsmgomes@yahoo.com.br
}

GOMES, V.S.M., TAMASHIRO, J.Y. \& SILVA, W.R. Seed inflow to a forest patch promoted by understory frugivorous birds. Biota Neotrop. 11(4): http://www.biotaneotropica.org.br/v11n4/en/ abstract?article+bn02211042011

\begin{abstract}
We studied the contribution of understory frugivorous birds to the seed inflow into a late successional Atlantic forest patch in southeastern Brazil. Five sampling units were established in the study site, each composed of a line of six mist nets and two adjacent plots containing six seed traps. Immigrant seed species were more frequent in seed traps during the rainy season, when fruit production was higher. On the other hand, the frequency of occurrence of immigrant seed species found in fecal samples of the understory frugivores was higher during the dry season. Although understory frugivorous birds were not responsible for the temporal pattern of the seed rain, they can play an important role in bringing edge plant species that will eventually colonize forest gaps, contributing to forest patch dynamics.
\end{abstract}

Keywords: Atlantic forest, frugivory, immigrant seeds, seed dispersal.

GOMES, V.S.M., TAMASHIRO, J.Y. \& SILVA, W.R. Entrada de sementes em um fragmento florestal promovida por aves frugívoras de subosque. Biota Neotrop. 11(4): http://www.biotaneotropica.org.br/v11n4/ pt/abstract?article+bn02211042011

Resumo: Estudamos a contribuição de aves frugívoras de subosque para a entrada de sementes em uma mancha de Floresta Atlântica secundária em estado avançado de regeneração no sudeste do Brasil. Foram estabelecidas cinco unidades amostrais, cada uma composta por uma linha de seis redes de neblina e duas parcelas adjacentes contendo seis coletores de sementes. Espécies de sementes imigrantes foram encontradas mais frequentemente nos coletores durante a estação chuvosa, quando houve maior produção de frutos. Por outro lado, a frequência de ocorrência de espécies imigrantes nas amostras fecais de aves de subosque foi maior durante a estação seca. Embora aves frugívoras de subosque não tenham sido determinantes para o padrão temporal da chuva de sementes, podem desempenhar um papel importante ao trazerem espécies de plantas de borda que poderão colonizar clareiras, contribuindo assim para a dinâmica de manchas florestais.

Palavras-chave: Floresta Atlântica, frugivoria, sementes imigrantes, dispersão de sementes. 


\section{Introduction}

Natural regeneration in tropical forests is greatly dependent upon a frequent seed rain, as most plants have seeds with rapid germination and low longevity (Garwood 1983, Vazquez-Yanes \& Orozco-Segovia 1993). Therefore, in these forests seed bank may play a minor role in natural regeneration $(\mathrm{Ng}$ 1983), what puts seed rain in the spotlights. Seed rain is composed by local or immigrant seeds in different proportions (Martinez-Ramos \& Soto-Castro 1993), depending on plant phenology (Rathcke \& Lacey 1985) and seed dispersal. Its patterns are importantly influenced by seed dispersal, which may favor germination and establishment, either by making seeds arrive at specific "safe sites" or by allowing the seeds to avoid competition or predation under the parent plant (Green 1983, Howe \& Miriti 2000).

Understand a seed rain pattern generated by vertebrate seed dispersers allows us to comprehend regeneration and organization of plant communities (McDonnell \& Stiles 1983, Loiselle et al. 1996, Hubbell et al. 1999). For seed rain generated by birds, it has been shown that it may depend on local plant diversity, structural characteristics of the habitat, local availability of resources (McClanahan \& Wolfe 1987, Levey 1990, Oldeman 1990), and behavior of the disperser species (Krijger et al. 1997, Jordano \& Godoy 2002).

Vertebrate seed dispersal gained another perspective in the context of forest fragmentation. Like in other tropical areas, most of the Brazilian Atlantic forest is reduced to small fragments of secondary forests (Ribeiro et al. 2009), vulnerable to indirect biological edge effects, such as plant invasion from the matrix through seed dispersal by animals (Murcia 1995). Thus, there is an urgent need to gather information on how forest fragments are influenced by their surroundings (Janzen 1983, Chimera \& Drake 2010), with implications for the conservation of natural preserves (Janzen 1986).

Literature commonly reports bird-mediated seed dispersal from forest to earlier successional habitats (e.g. Scot Duncan 2006, Herrera $\&$ Garcia 2010). However, it scarcely reports the opposite seed flow performed by birds, the influx of edge seeds into the forest. Indeed, it would not be surprising that the same bird species that are able to carry seeds off the forest could also introduce into the forest seeds ingested in the more open nearby habitats, as seem to be the case for several opportunistic edge-dweller forest frugivores (Restrepo et al. 1999). This seed counter-flow would present composition, spatial and temporal variation according to the differences in fruit phenology and habitat preferences by frugivorous birds, with possible consequences for the plant populations at local and regional scales. In this study we addressed the contribution of understory frugivorous birds to the influx of pioneer seed species into an Atlantic forest patch, as well as the composition and temporal patterns of the seed rain promoted by them.

\section{Material and Methods}

\section{Study area}

We collected data in a secondary forest tract of Atlantic forest with approximately 4 ha inside Intervales State Park (PEI), south of São Paulo State, southeastern Brazil (24'16' 09' S and 48 24' 56" W, $800 \mathrm{~m}$ asl). PEI is a 49,000 ha protected park well connected to three other reserves encompassing a total of 120,000 ha of continuous protected forest, being a mosaic of pristine/old-growth and secondary forests. Regional climate is characterized by rainfall throughout the year with the highest values being reached in the hottest months, from November to March. Annual mean temperature in the study year was $16.7^{\circ} \mathrm{C}\left(31^{\circ} \mathrm{C}\right.$ max and $\left.1.6^{\circ} \mathrm{min}\right)$ and the annual rainfall was $1543 \mathrm{~mm}$. Although variation occurs, the vegetation of the park is broadly classified as lower montane rain forest (700-1100 m asl; Oliveira-Filho \& Fontes 2000) and plant composition is influenced by the humid forests of Southern Brazil and the mesophilous forests of the interior plateau of São Paulo State (Fundação... 1997). The study area, located 1-2 km from the park administration office, was formerly a plantation and has been regenerating into a secondary forest over the last 50 years. It is surrounded by dirt roads, an arboretum, and another smaller forest tract, but mature forest can be found in a $1 \mathrm{~km}$ radius. Forest canopy is about $22 \mathrm{~m}$ high, with conspicuous individuals of Ocotea puberula (Rich.) Nees (Lauraceae) and the understory is dense with many individuals of Piper spp. L. (Piperaceae), Dichorisandra thyrsiflora J.C. Mikan (Commelinaceae), Heliconia farinosa Raddi (Heliconiaceae) and Psychotria suterella Müll. Arg. (Rubiaceae). For a more detailed description of understory structure, see Gomes \& Silva (2002).

\section{Sampling units}

We established five sampling units (SUs), each one containing a line of six mist nets $(12 \times 2.5 \mathrm{~m} ; 36 \mathrm{~mm}$ mesh $)$ and two plots of $10 \times 25 \mathrm{~m}$ adjacent to the nets (totaling 10 plots or $2,500 \mathrm{~m}^{2}$ ). Between April 1999 and March 2000, we captured birds monthly, for five days per month, one day at each SU, 6 hour per day (2160 net-hours). We marked all captured frugivorous birds with numbered aluminum bands provided by Cemave/Ibama (Ministry of Environment, Brazil). We considered legitimate frugivores those species that ingest seeds and void them intact (according to Snow 1981 and Sick 1997). We kept those birds in cloth bags for 30 to 60 minutes following capture, and then released them. After that, we inspected the bags for the presence of seeds, which we collected and preserved dry. We assumed that seeds found in bird feces would potentially be deposited on the adjacent plots if birds had not been captured. To sample seed rain we set six seed traps $\left(1 \mathrm{~m}^{2} ; 20 \mathrm{~cm}\right.$ high; $1 \mathrm{~mm}^{2}$ mesh $)$ inside each plot, totaling 60 traps in the whole study area, from which we collected seeds and ripe fruits caught. Although secondary dispersers (ants) could remove some seeds from the traps, or they could even rot in the traps between samplings, we noticed that the species collected in traps represented the true fruit availability for frugivores in the study area. We considered here only those seeds identified at least on the family level.

Once a month we counted (directly) or estimated (counting a branch or a part and extrapolating to the whole crown, when counting was not precise) ripe and unripe fruits inside the plots from all ornithochorous (sensu van der Pijl 1982) or zoochorous plants potentially consumed by birds (Ladrum 1986 apud Pizo 2002, Levey 1988, VSMG pers. obs.), considering not only plants totally inside the plots, as well as plants with their base and/or crown projected over the plots. We calculated the Fruit Abundance Index proposed by Levey (1988) to minimize large crop effects and we used it as a measure of ripe fruit abundance. Levey considered the following indexes for each interval of fruit abundance: (1) 1 to 10 ; (2) 11 to 25; (3) 26 to 50 ; (4) 51 to 100 ; (5) 101 to 200 ; (6) 201 to 500 ; (7) 501 to 1,000 , (8) 1,001 to 10,000 . We checked those species that did not produce fruits during the study period for their dispersal syndrome in Lorenzi (1998, 2000) or at the herbarium of the Universidade Estadual de Campinas (Herbário UEC).

Contrasting to resident seed species, immigrant ones were those neither recorded in any plot, nor in the study area outside the plots during random observations. We conducted those random observations on the main trail and along the mist net trails, totaling approximately $1500 \mathrm{~m}^{2}$ sampled every month. In our analyses, pioneer species, presumably capable of colonizing edge or gap habitats are always shown separately from the understory species. To assign the 
status of immigrant or resident to a seed we considered only those seeds identified at least on the genus level.

\section{Data analysis}

In order to verify the temporal pattern of seed immigration, we analyzed fruit production, seed rain, bird capture and fecal samples throughout 12 study months. To determine a possible relationship between ripe fruit production (independent) and presence of immigrant seeds in the traps (dependent) over the 12 months, we used Linear Regression Analyses. First we tested normality with the Kolmogorov-Smirnov test (Sokal \& Rohlf 1997), option Lilliefors (SYSTAT 1990). When normality was rejected, we used the square root transformation (Zar 1996), and tested for normality again. Then, we performed linear regression with SYSTAT (1990).

\section{Results}

\section{General aspects of the seed rain}

We recorded 48 fruiting plant species (Appendix) and 52 morphospecies in the seed rain inside the plots, from which we identified $73 \%$ (38) at least on the genus level (being eight immigrants). Despite 41 species presented ripe fruits, 11 (27\%) were never recorded at the local seed rain, indicating that we were not able to sample the entire seed rain. However, other seeds were recorded at the seed rain with no conspecifics in the same plot (letter $\mathrm{S}$ in Appendix), meaning that we were able to detect seed movement. Immigrant seeds represented $21 \%$ of the identified seeds and their adults were detected on the margins of the dirt road adjacent to the study area (Table 1). From the four typically pioneer species, three were present in one SU and one (Rubus urticifolius Poir.) in three. Immigrant species also represented $36 \%$ of seed species found in bird samples (10 species out of 28), from which the melastomes were represented by five species. Most of those immigrant species, both in bird samples and seed rain, typically inhabit forest edges and gaps (Table 1).

\section{Temporal pattern of seed immigration}

Immigrant seed species were more abundant in the seed rain (number of seed traps, square root transformed) when abundance of fruits was the highest (total fruit abundance) $\left(R^{2}=0.42 ; P=0.02\right.$; $\mathrm{n}=12 \mathrm{mo}$; Figure 1), although there was no relationship between fruit production and presence of local species in the seed rain (number of seed traps) $\left(R^{2}=0.20 ; \mathrm{P}=0.15 ; \mathrm{n}=12 \mathrm{mo}\right.$; Figure 1$)$.

On the other hand, understory birds brought immigrant seeds to the study area during 10 months of the year, mainly from May to September, a period of low fruit availability. Ruby-crowned Tanager Tachyphonus coronatus (Vieillot, 1822) and Black-goggled Tanager Lanio melanops (Vieillot, 1818) (Passeriformes, Thraupidae) seemed to account for the main influx of those seeds (Table 2), mainly L. melanops, from which we captured unbanded individuals with immigrant seeds in May and in August 1999.

\section{Discussion}

Understory birds brought seeds into the area during the season of low fruit availability, when seeds of melastome species predominated in fecal samples. In tropical forests, many melastome species produce fruit year-round (Snow 1965, Poulin et al. 1999) and they are heavily consumed by birds, especially small passerine species (Stiles \& Rosselli 1993, Poulin et al. 1999, Silva et al. 2002). Levey (1988) reported that during a decline of fruits in primary forest, frugivorous birds tend to move to a secondary one, where fruit abundance may sometimes surpass that of the former habitat. Among the understory species, Lanio melanops and, in a lesser degree Tachyphonus coronatus, seem to be the main carriers of immigrant seeds to the study area. During periods of shortage of fruits (present study) and insects (light traps in PEI, P. C. Bispo unpublished data), L. melanops takes part in multi-specific associations (Rodrigues et al. 1994, Machado 1999). Also, both species usually extend their movements into open areas (W. R. Silva unpublished data).

Those two Thraupidae species and other understory birds played an important role to the arrival of immigrant melastomes, which,

Table 1. Origin $(\mathrm{SR}=$ seed rain, $\mathrm{BF}=$ bird feces $)$ and typical habitat ${ }^{\mathrm{a}}(\mathrm{E}=$ Forest edge or gap; $\mathrm{I}=$ Forest interior $)$ of the immigrant seed species to the study area, in Intervales State Park.

Tabela 1. Origem ( $\mathrm{SR}=$ chuva de sementes, $\mathrm{BF}=$ fezes de aves $)$ e habitat típico ${ }^{\mathrm{a}}(\mathrm{E}=$ borda ou clareira; $\mathrm{I}=$ interior $)$ das espécies de sementes imigrantes na área de estudo, no Parque Estadual Intervales.

\begin{tabular}{|c|c|c|c|c|}
\hline Family & Species & Origin & Habitat & Frequency $^{b}$ \\
\hline Aquifoliaceae & Ilex brevicuspis Reissek & SR & $\mathrm{E}$ & 1 \\
\hline \multirow[t]{2}{*}{ Euphorbiaceae } & Sapium glandulosum (L.) Morong & SR & $\mathrm{E} / \mathrm{I}$ & 2 \\
\hline & Tetrorchidium rubrivenium Poepp. & SR & $\mathrm{E} / \mathrm{I}$ & 4 \\
\hline \multirow[t]{5}{*}{ Melastomataceae } & Leandra australis (Cham.) Cogn. & $\mathrm{BF}$ & $\mathrm{E}$ & 5 \\
\hline & Leandra cf. pilonensis Wurdack & $\mathrm{BF}$ & I & 5 \\
\hline & Leandra cf. sabiaensis Brade & $\mathrm{BF}$ & $\mathrm{E}$ & 1 \\
\hline & Miconia cabucu Hoehne & $\mathrm{BF}$ & I & 2 \\
\hline & Miconia pusilliflora (DC.) Naudin & $\mathrm{BF} / \mathrm{SR}$ & I & 2 \\
\hline Phyllanthaceae & Hieronyma alchorneoides Allemão & SR & $\mathrm{E} / \mathrm{I}$ & 3 \\
\hline Rhamnaceae & Rhamnus sphaerosperma Sw. & SR & $\mathrm{E}$ & 1 \\
\hline \multirow[t]{3}{*}{ Rosaceae } & Rubus brasiliensis Mart. & $\mathrm{BF}$ & $\mathrm{E}$ & 1 \\
\hline & Rubus rosifolius $\mathrm{Sm}$. & $\mathrm{BF}$ & $\mathrm{E}$ & 3 \\
\hline & Rubus urticifolius Poir. & $\mathrm{BF} / \mathrm{SR}$ & $\mathrm{E}$ & 3 \\
\hline \multirow[t]{2}{*}{ Rubiaceae } & Coccocypselum hasslerianum Chodat & $\mathrm{BF}$ & I & 1 \\
\hline & Galium hypocarpium (L.) Endl. ex Griseb. & $\mathrm{BF}$ & $\mathrm{E}$ & 1 \\
\hline Solanaceae & Solanum americanum Mill. & SR & $\mathrm{E}$ & 1 \\
\hline
\end{tabular}

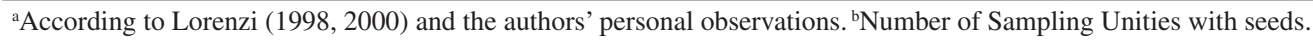

a'De acordo com Lorenzi $(1998,2000)$ e observações dos autores. ${ }^{b}$ Número de unidades amostrais com sementes. 


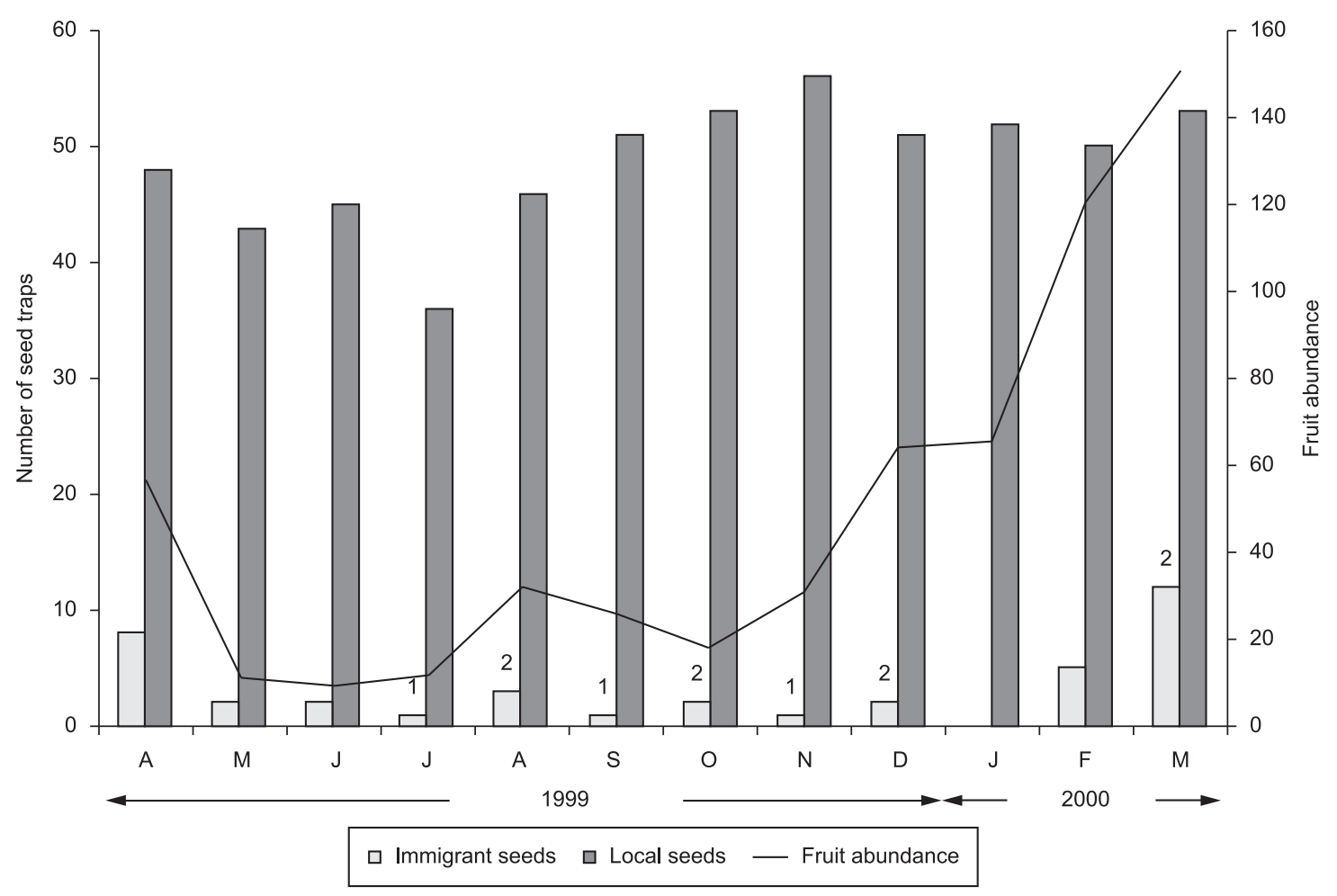

Figure 1. Total number of seed traps with immigrant or local seed species ( $\mathrm{n}=60$ in each month, being 5 Sampling Unities $\times 12$ traps) and total abundance of ripe fruits (2,500 $\mathrm{m}^{2}$ sampled during 12 months) at the study area, in Intervales State Park. Above the light grey bars are numbers of traps with pioneer species.

Figura 1. Número total de coletores de sementes com espécies de sementes imigrantes ou locais ( $\mathrm{n}=60$ em cada mês, sendo 5 unidades amostrais $\times 12$ coletores) e abundância total de frutos maduros $\left(2.500 \mathrm{~m}^{2}\right.$ amostrados por 12 meses) na área de estudo, no Parque Estadual Intervales. Acima das barras cinzas claras estão os números de coletores com espécies pioneiras.

Table 2. Occurrence of site immigrant pioneer seed species in bird fecal samples (taxonomy following CBRO (Comitê... 2011)) at the study area, in Intervales State Park.

Tabela 2. Ocorrência de espécies de sementes imigrantes pioneiras (de borda ou clareira) nas amostras fecais das aves (taxonomia segundo CBRO (Comitê... 2011)) na área de estudo, no Parque Estadual Intervales.

\begin{tabular}{|c|c|c|c|c|c|}
\hline Family & $\begin{array}{c}\text { Bird } \\
\text { species }\end{array}$ & $\begin{array}{c}\text { N. } \\
\text { individuals } \\
\text { captured }\end{array}$ & $\begin{array}{c}\text { Total N. fecal } \\
\text { samples with } \\
\text { seeds } \\
\end{array}$ & $\begin{array}{c}\text { \% of samples with } \\
\text { immigrant pioneer } \\
\text { seed species }\end{array}$ & $\begin{array}{c}\text { N. seed species in } \\
\text { fecal samples } \\
\text { (pioneer species) }\end{array}$ \\
\hline Cardinalidae & Habia rubica (Vieillot, 1817) & 6 & 3 & 0 & $2(0)$ \\
\hline \multirow[t]{3}{*}{ Thraupidae } & Saltator similis d'Orbigny \& Lafresnaye, 1837 & 2 & 1 & 0 & $2(0)$ \\
\hline & Tachyphonus coronatus (Vieillot, 1822) & 18 & 17 & 18 & $11(5)$ \\
\hline & Lanio melanops (Vieillot, 1818) & 20 & 14 & 29 & $8(3)$ \\
\hline \multirow[t]{2}{*}{ Turdidae } & Turdus albicollis Vieillot, 1818 & 16 & 12 & 0 & $8(0)$ \\
\hline & Turdus rufiventris Vieillot, 1818 & 6 & 1 & 100 & $2(1)$ \\
\hline \multirow[t]{2}{*}{ Pipridae } & Chiroxiphia caudata (Shaw \& Nodder, 1793) & 18 & 22 & 5 & $11(2)$ \\
\hline & Neopelma chrysolophum Pinto, 1944 & 2 & 1 & 0 & $1(0)$ \\
\hline Tityridae & Schiffornis virescens (Lafresnaye, 1838) & 5 & 7 & 0 & $9(0)$ \\
\hline Tyrannidae & Attila rufus (Vieillot, 1819) & 1 & 0 & 0 & 0 \\
\hline Rynchocyclidae & Mionectes rufiventris Cabanis, 1846 & 5 & 0 & 0 & 0 \\
\hline \multirow[t]{2}{*}{ Vireonidae } & Hylophilus poicilotis Temminck, 1822 & 2 & 0 & 0 & 0 \\
\hline & Vireo olivaceus (Linnaeus, 1766) & 1 & 0 & 0 & 0 \\
\hline Total: & 13 & 102 & 78 & - & - \\
\hline
\end{tabular}

however, are not abundant as established plants. It seems that most of the immigrant seed species carried by understory birds are edge species that reach the area but fail to recruit adult individuals in the understory, although they can probably grow in gaps and eventually fruit, providing food for understory frugivores (Blake \& Hoppes 1986, Levey 1990). Their influence to forest dynamics may be crucial, once gap colonization may depend on a constant arrival of seeds (AlvarezBuylla \& Martinez-Ramos 1990). However, natural regeneration has changed the study area into a forest over the last 50 years, gradually favoring the establishment of forest plant species instead of edge ones. Perhaps the role of understory frugivorous species in our study area was more determinant in the beginning of ecological succession. At 
further stages, however, their influence on the vegetation structure is diminished, although their movements throughout the area are still dependent on the spatial and temporal configuration of species fruit composition and abundance. The importance of immigrant seeds may depend on the disturbance history of a forest patch and it will be greater in patches with high canopy turnover rates (Martinez-Ramos \& Soto-Castro 1993).

The asynchrony in the arrival of immigrant seeds to the study area recorded from bird feces and seed traps was noteworthy. The peak of abundance of immigrant seed species caught on traps occurred when fruit availability in the area reached the highest level. This may be due to a "crop size effect" on the landscape scale, i.e., a patch with high abundance of fruits may attract dispersers (Herrera 1985, Terborgh 1986, Levey 1988, Loiselle \& Blake 1991) and may increase the chances of those dispersers bring other seeds to that patch. Since understory avian frugivores solely may not explain this discrepancy, other frugivores might be depositing immigrant seeds in the traps, like Aburria jacutinga (Spix, 1825) and Procnias nudicollis (Vieillot, 1817), large mid-level and canopy frugivorous species frequently observed in the study area and in nearby areas (Pizo et al. 2002, Silva et al. 2002), as well as many understory bat species (Passos et al. 2003), who are also frequent consumers of some of the zoochorous plants studied (Piper spp., Cestrum spp., Ficus spp. and Solanum spp., see Silva (2003)).

We conclude that understory frugivorous birds are important for the maintenance of a constant seed inflow from edge habitats, mainly melastomes, throughout the stages of ecological succession, which may play a critical role on the forest gap dynamics of Atlantic forest patches.

\section{Acknowledgements}

To Antônio Máximo and the Intervales State Park crew for assisting fieldwork and Sandra M. J. P. Silva for assisting laboratory work. Botanists Maria de Fátima Freitas, João Renato Stehmann, Maria Lúcia Kawasaki, Sigrid L. Jung-Mendaçoli, Rodolfo A. de Figueiredo and Renato Goldenberg kindly helped in plant identification. V. S. M. Gomes was supported by a CNPq scholarship (through Programa de Pós-Graduação em Ecologia/Unicamp). FAPESP (Grant 98/05090-6) and FMB supported W. R. Silva. Érica Hasui, Flavio N. Ramos, Mauro Galetti, Marco A. Pizo and João Semir contributed with valuable comments to an earlier version of this manuscript. Marcus F. Oliveira and three anonymous reviewers contributed to the final version.

\section{References}

ALVAREZ-BUYLLA, E.R. \& MARTINEZ-RAMOS, M. 1990. Seed bank versus seed rain in the regeneration of a tropical pioneer tree. Oecologia 84:314-325.

ANGIOSPERM PHYLOGENY GROUP -APG II. 2003. An update of the Angiosperm Phylogeny Group classification for the orders and families of flowering plants: APG II. Bot. J. Linn. Soc. 141:399-436.http://dx.doi. org/10.1046/j.1095-8339.2003.t01-1-00158.x

BLAKE, J.G. \& HOPPES,W.G. 1986. Influence of resource abundance on use of tree-fall gaps by birds in an isolated woodlot. Auk 103:328-340.

CHIMERA, C.G. \& DRAKE, D.R. 2010. Patterns of seed dispersal and dispersal failure in a Hawaiian dry forest having only introduced birds. Biotropica 42(4):493-502. http://dx.doi.org/10.1111/j.17447429.2009.00610.x

COMITÊ BRASILEIRO DE REGISTROS ORNITOLÓGICOS-CBRO. 2011. Listas das aves do Brasil. 10nd ed. http://www.cbro.org.br (ultimo acesso em 20/04/2011).
FUNDAÇÃO FLORESTAL. 1997. Parque Estadual Intervales. Plano de Gestão Ambiental, fase 1. Fundação para a Conservação e a Produção Florestal do Estado de São Paulo, São Paulo, 200 p.

GARWOOD, N. 1983. Seed germination in a seasonal tropical forest in Panama: a community study. Ecol. Monogr. 53:159-181. http://dx.doi. org/10.2307/1942493

GOMES, V.S.M. \& SILVA,W.R. 2002. Spatial variation in understory frugivorous birds in an Atlantic Forest fragment of southeastern Brazil. Ararajuba 10:219-225.

GREEN, D.S. 1983. The efficacy of dispersal in relation to safe site density. Oecologia 56:356-358. http://dx.doi.org/10.1007/BF00379712

HERRERA, C.M. 1985. Habitat-consumer interactions in frugivorous birds. In Habitat selection in birds (M.L. Cody, ed.).Academic Press, Inc. Orlando, p.341-365.

HERRERA, J.M. \& GARCIA, D. 2010. Effects of forest fragmentation on seed dispersal and seedling establishment in ornithochorous trees. Conserv. Biol. 24(4):1089-1098. PMid:20184646. http://dx.doi. org/10.1111/j.1523-1739.2010.01459.x

HOWE, H.F. \& MIRITI, M.N. 2000. No question: seed dispersal matters. Tree 15:434-436. http://dx.doi.org/10.1016/S0169-5347(00)01965-0

HUBBELL, S.P., FOSTER, R.B.,O`BRIEN, S.T., HARMS, K.E., CONDIT, R., WECHSLER, B., WRIGHT, S.J. \& LOO DE LAO, S. 1999. Light-gap disturbances, recruitment limitation, and tree diversity in a neotropical forest. Science 283:554-556.

JANZEN, D.H. 1983. No park is an island: increase in interference from outside as park size decreases. Oikos 41:402-410. http://dx.doi. org/10.2307/3544100

JANZEN, D.H. 1986. The eternal external threat. In Conservation Biology. The science of scarcity and diversity (M.E.Soulé, ed.). Sinauer Associates, Inc., Sunderland, p. 286-303.

JARDIM BOTÂNICO DO RIO DE JANEIRO-JBRJ. 2010. Lista de espéciesFlora do Brasil. http://floradobrasil.jbrj.gov.br/2010/ (último acesso em 20/04/2011).

JORDANO, P. \&GODOY, J.A. 2002.Frugivore-generated seed shadows: a landscape view of demographic and genetic effects. In Seed dispersal and frugivory: ecology, evolution and conservation (D.J. Levey, W.R. Silva \& M. Galetti, eds.).CAB International, Wallingford, p. 305-321.

KRIJGER, C.L., OPDAM,M., THERY, M. \& BONGERS,F. 1997. Courtship behaviour of manakins and seed bank composition in a French Guianan rain forest. J. Trop. Ecol. 13:631-636. http://dx.doi.org/10.1017/ S0266467400010774

LEVEY, D.J. 1988.Spatial and temporal variation in Costa Rican fruit and fruit-eating bird abundance. Ecol. Monogr. 58:251-269. http://dx.doi. org/10.2307/1942539

LEVEY, D.J. 1990. Habitat-dependent fruiting behaviour of an understorey tree, Miconia centrodesma, and tropical treefall gaps as keystone habitats for frugivores in Costa Rica. J. Trop. Ecol. 6:409-420. http://dx.doi. org/10.1017/S026646740000479X

LOISELLE, B.A. \& BLAKE, J.G. 1991. Temporal variation in birds and fruits along an elevational gradient in Costa Rica. Ecology 72:180-193. http:// dx.doi.org/10.2307/1938913

LOISELLE, B.A., RIBBENS, E. \& VARGAS, O. 1996. Spatial and temporal variation of seed rain in a tropical lowland wet forest. Biotropica 28:8295. http://dx.doi.org/10.2307/2388773

LORENZI, H. 1998. Árvores brasileiras: manual de identificação e cultivo de plantas arbóreas do Brasil. 2nd ed. Instituo Plantarum, Nova Odessa, v.2, $352 \mathrm{p}$.

LORENZI, H. 2000. Árvores brasileiras: manual de identificação e cultivo de plantas arbóreas do Brasil. 3nd ed. Instituo Plantarum, Nova Odessa, v. $1,352 \mathrm{p}$.

MACHADO, C.G. 1999. A composição dos bandos mistos de aves na Mata Atlântica da Serra de Paranapiacaba, no Sudeste Brasileiro. Rev. Bras. Biol. 59:75-85. http://dx.doi.org/10.1590/S0034-71081999000100010

MARTINEZ-RAMOS, M. \& SOTO-CASTRO, A. 1993. Seed rain and advanced regeneration in a tropical rain forest. In Frugivory and seed dispersal: ecological and evolutionary aspects, Vegetatio 107-108 (T. H. Fleming \& A. Estrada, eds.).Kluwer Academic Publishers, Dordrecht, p. 299-318. 
MCCLANAHAN, T.R. \& WOLFE, R.W.1987. Dispersal of ornithochorous seeds from forest edges in central Florida. Vegetatio 71:107-112.

MCDONNELL, M.J. \& STILES, E.W. 1983. The structural complexity of old-field vegetation and the recruitment of bird-dispersed plant species. Oecologia 56:109-116. http://dx.doi.org/10.1007/BF00378225

MURCIA, C. 1995. Edge effects in fragmented forests: implications for conservation. Tree 10:58-62. http://dx.doi.org/10.1016/S01695347(00)88977-6

NG, F.S.P. 1983. Ecological principles of tropical lowland rain forest conservation. In Tropical rain forest: ecology and management (S.L. Sutton, T.C. Whitmore \& A.C. Chadwick, eds.). Blackwell Science Publication, London, p. 359-375.

OLDEMAN, R.A.A. 1990. Forests: elements of silvology. Springer-Verlag, Berlin, 624 p. http://dx.doi.org/10.1007/978-3-642-75211-7

OLIVEIRA-FILHO, A.T. \& FONTES, M.A.L. 2000. Patterns of floristic differentiation among Atlantic Forests in Southeastern Brazil and the influence of climate. Biotropica 32:793-810.

PASSOS, F.C., SILVA, W.R., PEDRO, W.A. \& BONIN, M.R. 2003. Frugivoria em morcegos (Mammalia, Chiroptera) no Parque Estadual Intervales, sudeste do Brasil. Rev. Bras. Zool. 20:511-517. http://dx.doi.org/10.1590/ S0101-81752003000300024

PIZO, M.A. 2002.The seed-dispersers and fruit syndromes of Myrtaceae in the Brazilian Atlantic forest.In Seed dispersal and frugivory: ecology, evolution and conservation (D.J. Levey, W.R. Silva \& M. Galetti, eds.). CAB International, Wallingford, p.129-143.

PIZO, M.A., SILVA, W.R., GALETTI, M. \& LAPS, R.R. 2002. Frugivory in cotingas of the Atlantic forest of southeast Brazil. Ararajuba 10:177-185.

POULIN, B., WRIGHT, S.J.,LEFEBVRE, G. \& CALDERON,O. 1999. Interespecific synchrony and asynchrony in the fruiting phenologies of congeneric bird-dispersed plants in Panama. J. Trop. Ecol. 15:213-227. http://dx.doi.org/10.1017/S0266467499000760

RATHCKE, B. \&LACEY, E.P. 1985. Phenological patterns of terrestrial plants. Ann. Rev. Ecolog. Syst. 16:179-214. http://dx.doi.org/10.1146/ annurev.es.16.110185.001143

RESTREPO, C., GOMEZ, N. \& HEREDIA, S. 1999. Anthropogenic edges, treefall gaps, and fruit-frugivore interactions in a neotropical montane forest. Ecology80:668-685.

RIBEIRO, M.C., METZGER, J.P., MARTENSEN, A.C., PONZONI, F.J. \& HIROTA, M.M. 2009. The Brazilian Atlantic Forest: How much is left, and how is the remaining forest distributed? Implications for conservation. Biol. Conserv. 142:1141-1153. http://dx.doi.org/10.1016/j. biocon.2009.02.021
RODRIGUES, M., MACHADO, C.G.,ALVARES, S.M.R. \& GALETTI, M. 1994. Association of the Black-Goggled tanager (Trichothraupis melanops) with flushers. Biotropica 26:472-475. http://dx.doi. org/10.2307/2389245

SCOT DUNCAN, R. 2006. Tree recruitment from on-site versus off-site propagule sources during tropical forest succession. New For. 31:131150. http://dx.doi.org/10.1007/s11056-004-5395-7

SICK, H. 1997. Ornitologia Brasileira. Editora Nova Fronteira, Rio de Janeiro, $912 \mathrm{p}$.

SILVA, W.R. 2003. A importância das interações planta-animal no processo de restauração. In Restauração ecológica de ecossistemas naturais (P.Y. Kageyama, R.E. Oliveira, L.F.D. Moraes, V.L. Engel \& F.B. Gandara, orgs.). FEPAF, Botucatu, p. 77-90.

SILVA, W.R., DE MARCO, P., HASUI, E. \& GOMES, V.S.M. 2002.Patterns of fruit-frugivore interactions in two Atlantic forest bird communities of southeastern Brazil: Implications for conservation. In Seed dispersal and frugivory: ecology, evolution and conservation (D.J. Levey, W.R. Silva \& M. Galetti, eds.). CAB International, Wallingford, p. 423-435.

SNOW, D.W. 1965. A possible selective factor in the evolution of fruiting seasons in tropical forest. Oikos 15: 274-281. http://dx.doi. org $/ 10.2307 / 3565124$

SNOW, D.W. 1981. Tropical frugivorous birds and their food plants: a world survey. Biotropica 13: 1-14. http://dx.doi.org/10.2307/2387865

SOKAL, R.R. \& ROHLF,F.J. 1997. Biometry. The principles and practice of statistics in biological research. 3nd ed. W. H. Freeman and company, New York, $887 \mathrm{p}$.

STILES, F.G. \& ROSSELLI,L. 1993. Consumption of fruits of the Melastomataceae by birds: how diffuse is coevolution? In Frugivory and seed dispersal: ecological and evolutionary aspects, Vegetatio 107108(T.H. Fleming \& A. Estrada, eds.). Kluwer Academic Publishers, Dordrecht, p.57-73.

SYSTAT, 1990. SYSTAT 5.03 for windows. SYSTAT, Inc., Evanston.

TERBORGH, J. 1986. Community aspects of frugivory in tropical forests. In Frugivores and seed dispersal (A. Estrada \& T.H. Fleming, eds.). Dr. W Junk Publishers, Dordrecht, p.371-384. http://dx.doi.org/10.1007/97894-009-4812-9_32

VAN DER PIJL, L. 1982. Principles of dispersal in higher plants. SpringerVerlag, Berlin.

VAZQUEZ-YANES, C. \& OROZCO-SEGOVIA,A. 1993. Patterns of seed longevity and germination in the Tropical Rainforest. Ann. Rev. Ecolog. Syst. 24:69-87. http://dx.doi.org/10.1146/annurev.es.24.110193.000441

ZAR, J.H. 1996. Biostatistical Analysis. Prentice-Hall, Inc., London. 


\section{Appendix}

Appendix 1. Ornitochorous species found in the sampling units. Classification according to APG II (Angiosperm, 2003) and JBRJ (Jardim... 2010). $\left(\mathrm{E}=\right.$ established $^{\mathrm{a}}, \mathrm{F}=$ produced ripe fruits, $\mathrm{U}=$ produced only unripe fruits, $\mathrm{S}=$ present in the seed rain ${ }^{\mathrm{b}}$ )

Apêndice 1. Espécies Ornitocóricas encontradas nas unidades amostrais. Classificação de acordo com APG II (Angiosperm, 2003) e JBRJ (Jardim... 2010). $\left(\mathrm{E}=\right.$ estabelecido $^{\mathrm{a}}, \mathrm{F}=$ produziu frutos maduros, $\mathrm{U}=$ produziu somente frutos imaturos, $\mathrm{S}=$ presente na chuva de sementes $\left.{ }^{\mathrm{b}}\right)$

\begin{tabular}{|c|c|c|c|c|c|c|}
\hline Family & Species & SU I & SU II & SU III & SU IV & SU V \\
\hline Acanthaceae & Mendoncia puberula Mart. & - & - & - & $\mathrm{EF}$ & - \\
\hline \multirow[t]{2}{*}{ Anacardiaceae } & Schinus terebinthifolius Raddi & ES & EFS & S & $\mathrm{S}$ & S \\
\hline & Tapirira guianensis Aubl. & - & $\mathrm{E}$ & - & - & - \\
\hline Annonaceae & Guatteria australis A.St.-Hil. & EFS & $\mathrm{EF}$ & EUS & EFS & EFS \\
\hline Apocynaceae & Tabernaemontana catharinensis A.DC. & - & - & - & ES & EU \\
\hline Araliaceae & Oreopanax sp. & ES & ES & - & S & EFS \\
\hline Boraginaceae & Cordia ecalyculata Vell. & - & - & - & $\mathrm{E}$ & $\mathrm{E}$ \\
\hline Cannabaceae & Celtis iguanaea (Jacq.) Sarg. & - & - & - & - & EFS \\
\hline Cardiopteridaceae & Citronella megaphylla (Miers)R.A. Howard & $\mathrm{E}$ & $\mathrm{E}$ & - & $\mathrm{E}$ & - \\
\hline \multirow[t]{2}{*}{ Celastraceae } & Maytenus aquifolia Mart. & - & $\mathrm{E}$ & - & - & - \\
\hline & Maytenus robusta Reissek & - & - & - & $\mathrm{E}$ & - \\
\hline \multirow[t]{2}{*}{ Commelinaceae } & Dichorisandra thyrsiflora J.C. Mikan & $\mathrm{EF}$ & EUS & EFS & EFS & EFS \\
\hline & Tradescantia sp. & $\mathrm{EF}$ & - & - & - & - \\
\hline Cucurbitaceae & Wilbrandia hibiscoides Silva Manso & $\mathrm{E}$ & - & - & - & - \\
\hline Elaeocarpaceae & Sloanea monosperma Vell. & - & $\mathrm{E}$ & - & $\mathrm{EF}$ & $\mathrm{EF}$ \\
\hline Erythroxylaceae & Erythroxylum ambiguum Peyr. & - & $\mathrm{E}$ & - & EUS & - \\
\hline Euphorbiaceae & Alchornea triplinervia (Spreng.)Müll. Arg. & - & - & S & ES & S \\
\hline Lamiaceae & Aegiphila integrifolia (Jacq.) Moldenke & $\mathrm{E}$ & - & - & - & - \\
\hline \multirow[t]{4}{*}{ Lauraceae } & Nectandra cuspidata Nees & EUS & ES & EFS & EUS & ES \\
\hline & Nectandra mollis (Kunth) Nees & & & & $\mathrm{E}$ & \\
\hline & Ocotea puberula (Rich.) Nees & - & $\mathrm{E}$ & $\mathrm{EF}$ & EU & EFS \\
\hline & Unidentified & $\mathrm{E}$ & - & - & - & - \\
\hline Loganiaceae & Strychnos brasiliensis Mart. & - & $\mathrm{EF}$ & - & - & - \\
\hline Loranthaceae & Psittacanthus sp. & EFS & - & ES & EFS & EFS \\
\hline \multirow[t]{2}{*}{ Malpighiaceae } & Bunchosia fluminensis Juss. & - & $\mathrm{EF}$ & - & - & - \\
\hline & Unidentified & EU & - & - & $\mathrm{E}$ & - \\
\hline \multirow[t]{2}{*}{ Melastomataceae } & Leandra dasytricha (A.Gray)Cogn. & $\mathrm{EF}$ & - & - & $\mathrm{EF}$ & - \\
\hline & Miconia tristis Spring & - & - & EFS & EFS & - \\
\hline \multirow[t]{2}{*}{ Meliaceae } & Cabralea canjerana (Vell.)Mart. & - & $\mathrm{E}$ & $\mathrm{E}$ & - & $S$ \\
\hline & Trichilia pallens C.DC. & EU & EU & - & - & - \\
\hline Monimiaceae & Mollinedia floribunda Tul. & EFS & EFS & ES & EFS & $\mathrm{EF}$ \\
\hline \multirow[t]{2}{*}{ Moraceae } & Ficus sp. L. & $\mathrm{E}$ & - & $\mathrm{S}$ & - & $\mathrm{E}$ \\
\hline & Sorocea bonplandii (Baill.)W.C. Burger Lanj. \&Wess. Boer & $\mathrm{E}$ & - & E & $\mathrm{E}$ & - \\
\hline Heliconiaceae & Heliconia farinosa Raddi & - & $\mathrm{EF}$ & $\mathrm{E}$ & EU & $\mathrm{EF}$ \\
\hline \multirow[t]{3}{*}{ Myrsinaceae } & Ardisia guianensis (Aubl.)Mez & - & $\mathrm{EF}$ & - & - & - \\
\hline & Myrsine coriacea (Sw.)R.Br.ex Roem.\&Schult. & $S$ & EFS & $S$ & S & $S$ \\
\hline & Myrsine umbellata Mart. & $\mathrm{E}$ & - & - & - & - \\
\hline \multirow[t]{4}{*}{ Myrtaceae } & Calycorectes australis D. Legrand & $\mathrm{EF}$ & - & - & - & - \\
\hline & Campomanesia guazumifolia (Cambess.)O. Berg & - & - & - & $\mathrm{E}$ & - \\
\hline & Campomanesia neriiflora (O. Berg) Nied. & - & $\mathrm{E}$ & - & - & $\mathrm{EF}$ \\
\hline & Campomanesia sp. & S & - & ES & - & S \\
\hline
\end{tabular}

aPlants were considered established when they were trees with DBH $>2 \mathrm{~cm}$ or shrubs, herbs and lianas which had produced at least unripe fruits during the study. ${ }^{b}$ To seed rain, Commelinaceae seeds were computed here in Dichorisandra thyrsiflora; seeds of Cupania vernalis or Matayba juglandifolia were computed here in Cupania vernalis; Myrsine sp. was computed here in Myrsine coriacea.

${ }^{a}$ As plantas foram consideradas estabelecidas quando eram árvores com DAP $>2 \mathrm{~cm}$ ou arbustos, ervas e lianas que produziram pelo menos

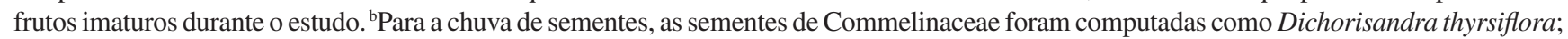
sementes de Cupania vernalis ou Matayba juglandifolia foram computadas como Cupania vernalis; Myrsine sp. foram computadas como Myrsine coriacea. 
Appendix 1. Continued...

\begin{tabular}{|c|c|c|c|c|c|c|}
\hline Family & Species & SU I & SU II & SU III & SU IV & SU V \\
\hline & Campomanesia xanthocarpa (Mart.) O. Berg & $\mathrm{EF}$ & - & - & - & - \\
\hline & Eugenia cuprea (O.Berg) Nied. & - & EFS & - & - & - \\
\hline & Eugenia mosenii (Kausel) Sobral & $\mathrm{E}$ & $\mathrm{E}$ & - & $\mathrm{E}$ & - \\
\hline & Eugenia verticillata (Vell.) Angely & S & EUS & EFS & $S$ & $S$ \\
\hline & Eugenia sp. & EU & - & - & $\mathrm{E}$ & $\mathrm{E}$ \\
\hline & $\begin{array}{l}\text { Marlierea eugeniopsoides (Kausel\&D.Legrand)D. } \\
\text { Legrand }\end{array}$ & $\mathrm{EF}$ & - & - & - & - \\
\hline & Marlierea sp. & ES & - & - & - & - \\
\hline & Myrcia splendens (Sw.) DC. & $\mathrm{E}$ & $\mathrm{EF}$ & $\mathrm{E}$ & EU & $\mathrm{EF}$ \\
\hline & Unidentified & - & - & $\mathrm{E}$ & - & - \\
\hline Nyctaginaceae & Guapira opposita (Vell.) Reitz & $\mathrm{EF}$ & $\mathrm{E}$ & $\mathrm{EF}$ & $\mathrm{E}$ & $\mathrm{E}$ \\
\hline Picramniaceae & Picramnia ramiflora Planch. & $\mathrm{EF}$ & - & - & - & - \\
\hline \multirow[t]{3}{*}{ Piperaceae } & Piper aduncum L. & EU & $\mathrm{EF}$ & $\mathrm{EF}$ & $\mathrm{EF}$ & $\mathrm{EF}$ \\
\hline & Piper corintoanum Yunck. & EUS & EU & EUS & EFS & EUS \\
\hline & Piper hoehnei Yunck. & $\mathrm{EF}$ & $\mathrm{E}$ & EU & EU & - \\
\hline Rosaceae & Prunus myrtifolia (L.) Urb. & $\mathrm{E}$ & - & - & - & - \\
\hline \multirow[t]{4}{*}{ Rubiaceae } & Psychotria longipes Müll.Arg. & - & - & - & $\mathrm{EF}$ & - \\
\hline & Psychotria sp. & EU & - & $\mathrm{S}$ & $S$ & - \\
\hline & Psychotria suterella Müll.Arg. & $\mathrm{EF}$ & EFS & EFS & EFS & EFS \\
\hline & Rudgea jasminoides (Cham.) Müll.Arg. & EU & $\mathrm{EF}$ & ES & EFS & - \\
\hline Rutaceae & Zanthoxylum fagara (L.) Sarg. & $\mathrm{E}$ & - & $\mathrm{E}$ & $\mathrm{E}$ & - \\
\hline \multirow[t]{3}{*}{ Salicaceae } & Banara parviflora (A.Gray)Benth. & - & $\mathrm{E}$ & $\mathrm{E}$ & - & - \\
\hline & Casearia decandra Jacq. & EFS & $\mathrm{E}$ & $\mathrm{E}$ & EFS & $\mathrm{E}$ \\
\hline & Casearia sylvestris $\mathrm{Sw}$. & EFS & ES & EUS & EFS & $\mathrm{ES}$ \\
\hline \multirow[t]{4}{*}{ Sapindaceae } & Allophylus edulis (A.St.-Hil., A.Juss. \& Cambess.) Radlk. & EFS & EFS & EFS & EFS & EFS \\
\hline & Cupania vernalis Cambess. & $\mathrm{ES}$ & S & $\mathrm{S}$ & ES & ES \\
\hline & Matayba juglandifolia (Cambess.) Radlk. & - & EU & - & - & - \\
\hline & Paullinia uloptera Radlk. & $\mathrm{E}$ & - & - & - & - \\
\hline Sapotaceae & Chrysophyllum cf. marginatum (Hook.\&Arn.)Radlk. & - & $\mathrm{E}$ & - & - & - \\
\hline Smilacaceae & Smilax elastica Griseb. & - & EF & - & - & - \\
\hline \multirow[t]{4}{*}{ Solanaceae } & Cestrum axillare Vell. & $\mathrm{EF}$ & - & - & EU & $\mathrm{EF}$ \\
\hline & Solanum cf. argenteum Dunal & - & - & $\mathrm{E}$ & - & - \\
\hline & Solanum sanctae-catharinae Dunal & - & - & - & S & EFS \\
\hline & Unidentified & - & $\mathrm{E}$ & - & - & - \\
\hline Symplocaceae & Symplocos estrellensis Casar. & S & - & - & EFS & S \\
\hline Urticaceae & Urera baccifera (L.) Gaudich. ex Wedd. & - & - & - & EU & EU \\
\hline Violaceae & Hybanthus atropurpureus (A.St.-Hil.) Taub. & - & E & - & - & - \\
\hline Total E & 78 & 41 & 39 & 26 & 39 & 28 \\
\hline Total F+U & 48 & 25 & 20 & 13 & 25 & 19 \\
\hline Total S & 30 & 16 & 15 & 25 & 28 & 23 \\
\hline
\end{tabular}

aPlants were considered established when they were trees with DBH $>2 \mathrm{~cm}$ or shrubs, herbs and lianas which had produced at least unripe fruits during the study. ${ }^{\text {}}$ To seed rain, Commelinaceae seeds were computed here in Dichorisandra thyrsiflora; seeds of Cupania vernalis or Matayba juglandifolia were computed here in Cupania vernalis; Myrsine sp. was computed here in Myrsine coriacea.

${ }^{a}$ As plantas foram consideradas estabelecidas quando eram árvores com DAP $>2 \mathrm{~cm}$ ou arbustos, ervas e lianas que produziram pelo menos

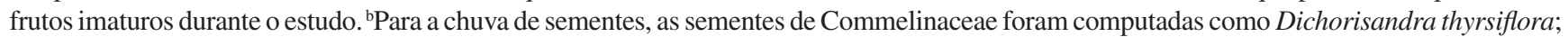
sementes de Cupania vernalis ou Matayba juglandifolia foram computadas como Cupania vernalis; Myrsine sp. foram computadas como Myrsine coriacea. 